\title{
SPANISH HOUSING MARKETS, 1904-1934: NEW EVIDENCE*
}

\author{
JUAN CARMONA \\ Universidad Carlos III de Madrid ${ }^{\mathrm{a}}$ \\ MARKUS LAMPE \\ Universidad Carlos III de Madrid $^{\mathrm{b}}$ \\ JOAN R. ROSÉS
}

London School of Economics and Political Science ${ }^{\mathrm{c}}$

\begin{abstract}
This article makes the first systematic attempt to analyse quantitatively the evolution of Spanish housing markets from 1904 to 1934, a period of dramatic changes in housing demand as a consequence of substantial income and demographic growth. In order to do so, we collect a new database on houses sold and their prices using data from the Registrar's Yearbooks. Furthermore, we construct a new hedonic index of real housing prices for Spain and its provinces. To our surprise, we found that real housing prices rose slightly over the entire period and, hence, that housing supply responded effectively to new demand for housing.
\end{abstract}

Keywords: housing regulation, hedonic prices, urbanization

JEL Code: N93, N94, R30

\footnotetext{
* Received 29 April 2013. Accepted 28 January 2014. The authors would like to thank to the editor of this Journal, Blanca Sánchez-Alonso, and three anonymous referees for their helpful comments and suggestions. Financial support was received by the Spanish Ministry of Economy and Competitiveness projects: 2013/00066/001 (Juan Carmona), ECO2011-25713 (Markus Lampe) and ECO2012-39169-C03-01 (Joan R. Rosés). The usual disclaimer applies.

a Departamento de Ciencias Sociales and Instituto Figuerola, Universidad Carlos III de Madrid, C/Madrid 126, 28903 Getafe, Spain.jucar@clio.uc3m.es

b Departamento de Ciencias Sociales and Instituto Figuerola, Universidad Carlos III de Madrid, C/Madrid 126, 28903 Getafe, Spain. markus.lampe@uc3m.es

c Departament of Economic History, London School of Economics and Political Science, Houghton Street, London WC2A 2AE. J.R.Roses@lse.ac.uk
} 


\section{RESUMEN}

Este articulo realiza el primer intento sistemático de analizar cuantitativamente la evolución del mercado de la vivienda en España desde 1904 a 1934, un periodo donde se experimentaron cambios dramáticos en la demanda de vivienda como consecuencia del notable crecimiento económico y demográfico. Para realizar este nuevo análisis, los autores han reunido una nueva base de datos con información procedente de los anuarios de los registradores de la propiedad. Además han construido un nuevo índice de precios hedónicos de la vivienda para el conjunto del país y sus provincias. De manera sorprendente, la nueva evidencia indica que los precios reales de la vivienda aumentaron solo ligeramente durante el periodo y que, en consecuencia, la oferta de vivienda respondió de manera efectiva a la nueva demanda.

Palabras Clave: Regulación de la vivienda, Precios hedónicos, Urbanización.

\section{INTRODUCTION}

Housing markets play a central role in the process of economic development, especially in periods of rapid demographic and structural change in a developing economy. Unfortunately, the systematic analysis of the evolution of housing markets and prices has not been very common in economic history ${ }^{1}$. This negligence is even more surprising if one takes into account that during most of contemporary history the major part of private investment was devoted to housing, and residential buildings were the main component of capital stock (Prados de la Escosura and Rosés 2009) ${ }^{2}$.

One of the most interesting periods in the history of housing in Spain is that between 1904 and 1934. During these thirty years, housing markets were subject to a substantial demand shift and several unexpected shocks ${ }^{3}$.

1 A notable exception is Williamson $(1990,1994)$ for the period of the English Industrial Revolution, and the substantial literature on racial housing discrimination in the United States (see, e.g. Collins and Margo 2003).

2 The scarce literature is mainly devoted to the period from 1840 to 1890 , when the liberalisation of housing markets took place and urbanisation accelerated with the destruction of the walls. See, for example, Ayllón et al. (1989), Galiana and Llop (1989), García Delgado (1992) and Rodríguez Chumillas (1989).

3 There are several alternative models that explain the basics behind the demand for housing. However, there is a certain agreement in the literature that demand for housing is a positive function of income, demographic growth (particularly migrations and the creation of new families) and the access to mortgages and a negative function of the user cost of capital (interest rates) and unemployment rates. Similarly, the literature agrees that the supply of housing is a function of the cost of construction, land prices and interest rates. Obviously, the relation between supply and 
Domestic migration increased without precedent and many people moved from the countryside to cities and from agrarian to industrialising provinces (Silvestre 2005). Regional income inequality increased rapidly and peaked in the first third of the $20^{\text {th }}$ century (Rosés et al. 2010). Simultaneously, demographic transition took place, leading to an unprecedented rise in the number of new families (Pérez Moreda 1985). Spain's financial system also suffered major transformations as banking, financial intermediation and the volume of credits expanded (Martín Aceña 1985). As a consequence of this series of far-reaching changes, urbanisation rates rose (Reher 1986) and the housing supply increased substantially (Prados de la Escosura 2003; Tafunell $2005)^{4}$. Despite these major developments, housing regulation remained minimal and public authorities hardly intervened in housing and urban land markets (Bassols 1973).

How did housing markets react to these major economic and social transformations? What institutional structures determined the response of the market to these transformations? How many houses were traded? What happened to housing prices? Did urban property prices shoot through the roof as demand increased? These questions are central not only to our understanding of Spanish housing markets, but also to our comprehension of the evolution of the Spanish economy during this period. The economic costs of any failure in housing markets would have been enormous due to the fact that Spain was a developing country and housing investment represented a large share of total investment during the first third of the $20^{\text {th }}$ century.

Fortunately, we have an extraordinary and underutilised source which collects detailed housing price information for all Spanish provinces: the Registrar's Yearbooks (Dirección del Registro de la Propiedad y del Notariado). Information is of rare quality since price underreporting could be considered minimal, at least, during the period previous to the Civil War (Carmona and Rosés 2012). This source contains information not only on the number and value of houses sold but also on the number and value of mortgages and other similar financial instruments, as well as the value and number of houses inherited.

In this paper, therefore, our main objective is to establish the basic knowledge on the evolution of urban real estate markets, that is, information on the institutional infrastructure of the markets, transaction volumes and prices of urban non-farm property in Spain ${ }^{5}$. Specifically, in the following

(F'note continued)

demand is mediated by institutional factors (mainly zoning regulations) and the availability of land (geography). For a good review of the literature, see Malpezzi (1999).

4 Sparse evidence on licenses for new houses also underlined the rapid increase in new constructions. See, Fernández Clemente and Forcadell (1992) on Zaragoza, Sorribes (1992) on Valencia and Tafunell (1992) on Barcelona.

5 To be clearer, here we only consider the outcome (equilibrium) of the basic model of housing (see previous footnote 3 ) and the institutional determinants of the market. Therefore, we leave for 
section we review the institutional structure of Spanish housing markets. We then construct a new series of housing transactions. Finally, we calculate average housing prices, more specifically, quality- and inflation-adjusted real urban non-farm property price series for Spain, its macro-regions and its largest provinces (measured by population). The main result of the paper is the evidence of a surprising long-run stability of both inflation- and quality-adjusted house prices in a period of structural change and constant fluctuations in the macroeconomic environment.

\section{THE INSTITUTIONAL STRUCTURE OF THE SPANISH HOUSING MARKET}

Before we investigate the Spanish housing market, we have to consider that markets do not develop in isolation. Their institutional framework must be sufficiently developed to allow for the construction of new dwellings and the transfer of real estate among economic agents. As the reader may observe over the following pages, the main role of the government in housing markets during the period under study was to enforce property rights while its direct market participation was very limited and circumstantial. In other words, Spanish housing policy was more liberal than interventionist, although some measures in this direction were timorously implemented.

To enhance efficiency in housing markets, contract law and land use regulation ${ }^{6}$ should fulfil a list of requirements ${ }^{7}$. In particular, property rights should be transparent, enforceable, emanate from a social consensus and participants should agree on the final arbiter of disputes (Malpezzi 1999). Regarding housing transactions, property rights should be easily and fully transferrable from seller to purchaser (Jaffe and Louziotis 1996). In the case of tenancy markets, tenant and landlord rights must be well-defined; there must be clear remedies for violation by either party; rights and obligations should be freely negotiated representing the outcome of a competitive market process (Malpezzi 1999). Also, the possibility and causes of eviction in the rental market should be clearly enumerated (Jimenez 1984). Finally, to facilitate the external finance of housing transactions, laws should allow the

\footnotetext{
(F'note continued)

further research a more detailed analysis of the determinants of housing supply and demand and the corresponding elasticities.

6 According to Malpezzi (1999), contract law is that body of law which regulates the formation and enforcement of contracts. Specifically, in the case of real estate, it deals with the transfer and allocation of property and property rights, and disputes on those rights. Land use regulation comprises the body of formal (law, regulations) and informal (custom) rules that governs the use of those rights. These regulations generate several different instruments like zoning ordinances, subdivision regulations, building and housing codes, and private deed restrictions.

7 See, for example, Alchian and Demsetz (1973), Coase (1960), Demsetz (1967) and Williamson (1975); and the survey of Malpezzi (1999).
} 
possibility of foreclosure for the non-payment of debt or other violation of the obligations of ownership (Malpezzi 1999).

The initial pillar for developing enforceable and transparent property rights is the creation of a system for formal registration of real estate property. The traditional system of backing real estate property in Spain had been based on a network of notaries since the $13^{\text {th }}$ century. The notary verified the property rights, drafted the legal sales contract and deed. However, the system was expensive, not perfectly transparent and highly decentralised. Furthermore, information regarding ownership was sometimes imperfect. To increase the efficiency of registration, the Bourbons created a government-sponsored system of mortgage registry (the Contaduría de Hipotecas) in 1768 (Peset 1978, p. 699). The new system of registration was cheap and therefore reduced information and transaction costs, but it was not universal or even widely used. Finally, in 1865, the old local system of ownership registration was replaced by a two-step system of registry, which solved disputes about property rights and gave legal backup to any transaction (Carmona and Rosés 2012) and was similar to the French system ${ }^{8}$. This institutional setting was characterised by a network of notaries with a local monopoly in registering real estate transactions. The parties, commonly the buyer, sent the records to the Real Estate Register, which collected the stamp duty on behalf of the government. This institution offered a cheap, universal and homogeneous system of public registry for all properties, even those not sold (Bono 1979).

In Spain, as in many European countries, the Liberal reforms in the first half of the $19^{\text {th }}$ century eliminated restrictions on real estate sales and established freedom of contract. The new authorities also derogated the legal apparatus of the Old Regime which allowed the coexistence of different property rights over real estate, the remaining feudal rights and many of the old forms of housing tenancy. However, Spanish law did not allow ownership of land to be held separately from the ownership of rights over that land, and in consequence, all floors of any building and its land were required to have only one owner. Indeed, this created a pecuniary entry barrier to the housing property for urban workers since, typically, houses in cities had several floors and, hence, their price was quite high. As a result, a large rental market was generated. This legal framework that linked land and housing property was in force until the end of the period under study ${ }^{9}$.

Another main contribution of the Liberal Revolution to the construction of the modern housing market was the Residential Tenancies Act ${ }^{10}$. This law

\footnotetext{
8 On the French system, see Gouriéroux and Laferrère (2009).

9 The requirement of joint ownership of land and the entirety of all buildings on it was reformed by Royal Order of 26 October 1939, which reformed article 396 of the Civil Code and the $8^{\text {th }}$ article of the Mortgage Act.

${ }^{10}$ Royal Order of 9 April 1842, which updates the law of 8 June 1813.
} 
fully liberalised the lease contract which had no restrictions on price and duration (Martínez Alcubilla 1892-1894). Eviction of renters only required 40 days' notice, and when the house was sold to a third party the leasing contract could be cancelled without compensation (Martínez Alcubilla 1892-1894, p. 696). The Residential Tenancies Act was criticised for giving too much power to landlords and not protecting the poor, with the logical consequence of a growing demand for rent control (Ortego 2006). Several proposals regarding rent control were approved by the Parliament but their effective application was limited (Bassols 1973, p. 230). In particular, high inflation rates prevalent during World War I (rents doubled in 5 years) led to a new regulation (Royal Decree of 21 June 1920) which restricted rent increases and established special boards to revise evictions (Martínez Alcubilla, Appendix 1921, ECR 419) ${ }^{11}$. However, this regulation was not enforced and rents continued rising (Ayuntamiento de Madrid 1929, p. 168).

In sharp contrast with the regulation affecting ownership registry, real estate transference and renting markets, the regulation of land use changed substantially from the Liberal Revolution to the Civil War (i.e. from mid$19^{\text {th }}$ century to 1936). Modifications of this regulation were generated by demands from two groups with, apparently, contradictory interests. On the one hand, landlords and developers criticised the absence of land for new houses and, on the other hand, social reformers and labor organisations complained about the lack of affordable housing for poor workers and poor hygiene conditions in crowded cities. Several studies in different periods (Comisión de Reformas Sociales 1985; Hauser 1902; Instituto de reformas sociales 1920, 1921; Ayuntamiento de Madrid 1929) complained about high rents, poor housing quality and sanitation conditions in Spain's urban areas. In particular, these studies censured the presence of dwellings in basements, dark houses, houses and rooms shared by different families, sublet renting, and warm beds. They proposed two types of reforms: the possibility of limiting rents, which was not implemented (as explained above), and different measures for increasing the supply of land available for new houses in the growing cities (Academia de Ciencias Morales y Políticas 1861).

The first zoning measure approved by the Spanish government was the plan for the development of Madrid and Barcelona (the Plan del Ensanche de Madrid y Barcelona), the largest and the fastest-growing cities in Spain in 1864. The main objectives of the plan were to regulate the characteristics of houses and to promote the rapid construction of new houses in order to respond to the growing demand for accommodation (Bassols 1973, pp. 252-257). The law established legal mechanisms and institutions (urbanisation committees) to coordinate the establishment and financing of the necessary infrastructure for the new urbanisation. The committees benefited from expropriations and

11 Note that these increases were well below the growth of the consumer price index, which more than doubled from 1914 to 1920 (see the data in Prados de la Escosura 2003). 
received government subsidies through tax exemptions (Bassols 1973). This model facilitated urban development but had the disadvantage of being inflexible. The plan was not adjusted to urban changes, which soon rendered it obsolete, and did not offer enough fiscal revenues to finance urban expansion and the concomitant increase in infrastructures. During the last quarter of the $19^{\text {th }}$ century, successive laws were passed in attempts to solve both problems $(1876,1892)$ and also created development plans for other major Spanish cities such as Bilbao and Valencia. The successive reforms of the plan forced the developers and builders to pay for the construction of streets and other urban infrastructure in exchange for tax exemptions (Bassols 1973).

However, acceleration of urban growth of Spanish cities around the turn of the century made the new plans of expansion obsolete and the available land for new construction scarce ${ }^{12}$. Developers and constructors tried to overcome this restriction by increasing urban density (e.g. increasing the amount of floors or constructing in space between houses) or by expanding accommodation to suburbs, an area that was not regulated by urbanisation plans. The fact is that the Spanish law allowed owners to build on their land without permission and size restrictions outside areas of the plan (Nuñez Granés 1920, p. 12). Contemporary reports highlight the disorder in construction and lack of infrastructures that predominated in such new urban developments, which became increasingly abundant ${ }^{13}$.

In sum, Spanish policy regarding housing was free-market based. The Liberal Revolution created an institutional framework that defined property rights and facilitated the operation of housing markets. On the one hand, ownership laws created a dual market of owners and renters, the latter being the majority of the Spanish population. Regulation of the leasing market protected landlords more than renters, who had relatively few rights. Indeed, this caused dysfunctions and affected the quality of housing but facilitated the transference of property. On the other hand, the regulation of land for urban development did not impede a continuous increase in the available land for new dwellings. When regulated land for urban construction became increasingly scarce, developers moved to suburbs. In suburbs, regulations simply did not exist but ownership of land and houses was recognised by the authorities. Therefore, there are no reasons to think that Spanish policy impeded the free operation of housing markets and the continuous expansion of the supply of new houses.

12 For example, Madrid in 1900 had doubled the urbanised surface and had practically exhausted the land for new houses in the zoning area.

13 The Instituto de Reformas Sociales elaborated numerous reports and proposed reforms for what they understood as one of the biggest problems of the working population, especially between 1904 and 1924. It proposed increasing the developable surface, so reducing density, and increasing the number and quality of public services. Some projects were launched but were not very successful or produced low-quality housing. 


\section{THE EVOLUTION OF HOUSING TRANSACTIONS}

Using the quantitative information of the Registrars' Yearbooks, we can reconstruct the evolution of Spanish urban housing markets from 1904 to 1934. In the yearbooks, "urban properties» (fincas urbanas) are defined as non-farm real estate property, including land and buildings on it; during our period, only complete properties (fincas) could be sold (see above). Both value (price) and number of transactions were recorded in the notaries and from there reported to the Dirección del Registro de la Propiedad y del Notariado. In its yearbooks numbers and values are aggregated to report the total value and number of sales in each province in each year. Dividing the first number by the second we obtain nominal average prices.

Unfortunately, the yearbook does not contain information about additional characteristics of the "fincas» whose ownership changed hands, such as the year of construction, number of floors and so on. We aim to approximate these characteristics and correct for their distribution across provinces and changes over time by incorporating information from decadal building censuses, as described below.

Figure 1 presents information on the number of urban buildings sold in the whole country and the six provinces with the most populated cities (i.e. Barcelona, Madrid, Biscay, Seville, Valencia and Saragossa). On average, 57,600 fincas urbanas were sold per year over our period. We divide the evolution in the number of houses sold into three periods. In the first decade of this series (i.e. from 1904 to 1913), 50,000 houses were sold per year. In other words, $\sim 1$ per cent of the total housing stock was traded each year ${ }^{14}$. In the following decade, from 1914 to 1923, the number of transactions grew at yearly rates of 5 per cent, from the low point of 48,500 sales in 1915 to the maximum of 73,500 in 1924 . In 1920 , about the 1.3 per cent of the housing stock was traded. During the remaining years (i.e. 1924-1933/1934), the number of market transactions began to decline, and the share of the stock traded decreased to 1.1 per cent in 1930. In 1933/1934, the number of transactions, c. 52,000, was slightly below that reported for 1904/1905.

As can be seen from the graph, the share of sales in the six provinces with the largest cities in the total increased over time from an average of 26 per cent in the first decade of our sample to an average of 29.5 per cent between 1914 and 1923, and almost 34 per cent between 1924 and 1933. These figures show that there is a cycle in the number of transactions for the whole of Spain, and much of this can be attributed to the turnover in the provinces with the largest cities.

14 More specifically, in 1900, the traded stock represented 1.2 per cent of the total housing stock. In 1910, the traded stock represented 1.0 per cent of the total housing stock. We obtained these figures by dividing the number of houses sold in 1904 and 1910 (interpolated) by the number of houses (edificios) counted in Spain's 1900 and 1910 censuses, respectively. The Canary Islands and possessions in Africa are excluded from both sales and stock volumes. 
FIGURE 1

THE EVOLUTION OF TRANSACTION NUMBERS FOR URBAN, NON-FARM PROPERTY IN SPAIN, ABSOLUTE NUMBERS.

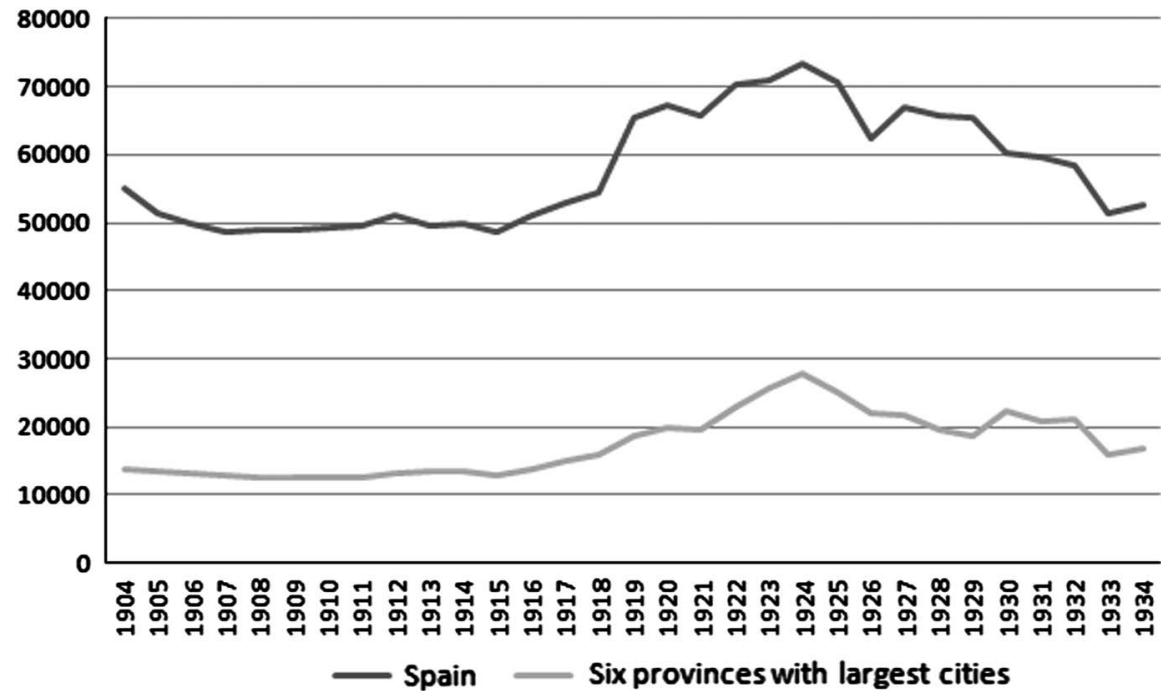

Sources: Anuario de la Dirección General. 1904-1934 (1909 and 1910 are interpolated).

Table 1 adds granularity to this picture by dividing Spain into the six macro-regions defined by Rosés and Sánchez-Alonso (2004). To give better insights into relative developments, we also contrast the evolution of transaction numbers in the mentioned provinces with the largest cities in comparison with those six provinces with the lowest population numbers in cities with more than 5,000 inhabitants (Reher 1986) ${ }^{15}$ and the lowest absolute provincial population $^{16}$. Since the absolute numbers of transactions depend on the number of inhabitants, panel b of Table 1 scales them to «sales per 1,000 inhabitants» in adjacent census years. Finally, since comparability over space might also be affected by different average size of buildings, we try to provide a simple adjustment by multiplying the number of sales by the average amount of floors in the corresponding building census (corresponding to the stock, not the flow of buildings) before dividing them by the population figures (see panel c in Table 1). Although, on average, buildings

15 Unfortunately, there is no census information that makes our urban, non-farm property building numbers comparable with the urban population living in them. «Urban», as defined by the building census, includes places much smaller than 5,000 inhabitants.

${ }_{16}$ See note to Table 1 on the provinces included in the latter six-city samples. 
TABLE 1

THE EVOLUTION OF HOUSING TRANSACTIONS, 1904-33

\begin{tabular}{|c|c|c|c|c|}
\hline & 1904-13 & 1914-23 & 1924-33 & 1904-33 \\
\hline & (1) & (2) & (3) & (4) \\
\hline \multicolumn{5}{|c|}{ (a) Mean number of market transactions per year } \\
\hline Andalusia & 13,896 & 16,514 & 14,947 & 15,016 \\
\hline Mediterranean & 17,231 & 21,986 & 26,327 & 21,882 \\
\hline Ebro Valley & 3,654 & 4,235 & 4,279 & 4,031 \\
\hline Northern Castile & 4,447 & 3,890 & 3,733 & 3,995 \\
\hline Southern Castile & 7,479 & 9,010 & 9,465 & 8,630 \\
\hline North & 3,519 & 4,028 & 4,672 & 4,051 \\
\hline Spain & 50,226 & 59,662 & 63,422 & 57,604 \\
\hline Six provinces largest cities & 12,751 & 17,279 & 20,728 & 16,898 \\
\hline Six provinces least urban population & 1,477 & 1,089 & 936 & 1,152 \\
\hline Six provinces lowest population & 1,754 & 1,561 & 1,467 & 1,580 \\
\hline \multicolumn{5}{|c|}{ (b) Mean number of market transactions of houses per 1,000 inhabitants } \\
\hline Andalusia & 3.6 & 3.9 & 3.2 & 3.6 \\
\hline Mediterranean & 3.9 & 4.6 & 4.9 & 4.5 \\
\hline Ebro Valley & 2.0 & 2.2 & 2.1 & 2.1 \\
\hline Northern Castile & 1.9 & 1.7 & 1.5 & 1.7 \\
\hline Southern Castile & 2.2 & 2.4 & 2.2 & 2.2 \\
\hline North & 1.0 & 1.0 & 1.1 & 1.0 \\
\hline Spain & 2.6 & 2.9 & 2.8 & 2.7 \\
\hline Six provinces largest cities & 3.2 & 3.8 & 3.7 & 3.6 \\
\hline Six provinces least urban population & 1.0 & 0.8 & 0.6 & 0.8 \\
\hline Six provinces lowest population & 1.7 & 1.6 & 1.4 & 1.5 \\
\hline \multicolumn{5}{|c|}{ (c) Mean number of market transactions of floors per 1,000 inhabitants } \\
\hline Andalusia & 6.2 & 6.7 & 5.5 & 6.1 \\
\hline Mediterranean & 7.9 & 9.4 & 9.7 & 9.1 \\
\hline Ebro Valley & 4.3 & 4.8 & 4.7 & 4.6 \\
\hline Northern Castile & 3.2 & 2.9 & 2.6 & 2.9 \\
\hline Southern Castile & 3.8 & 4.1 & 3.7 & 3.9 \\
\hline North & 1.8 & 1.9 & 2.1 & 1.9 \\
\hline Spain & 4.8 & 5.3 & 5.1 & 5.1 \\
\hline
\end{tabular}


TABLE 1 (Cont.)

\begin{tabular}{|l|l|l|l|l|}
\hline Six provinces largest cities & 6.8 & 8.0 & 7.5 & 7.5 \\
Six provinces least urban population & 1.9 & 1.4 & 1.1 & 1.4 \\
Six provinces lowest population & 3.6 & 3.2 & 2.9 & 3.2 \\
\hline
\end{tabular}

Notes: See text. Population numbers and floors per building for census/building census years 1910, 1920, 1930, respectively. Six provinces with largest cities are Barcelona, Madrid, Seville, Valencia, Biscay (Bilbao), Zaragoza. Six provinces with lowest urban population are Avila, Cuenca, Guadalajara, Orense, Segovia and Soria. Six provinces with lowest absolute population are Alava, Guadalajara, Logrono (La Rioja), Palencia, Segovia and Soria.

Sources: See Figure 1 and Population census for the respective years.

are slightly taller in the north than in the south of the country, especially in the Basque Country, this adjustment changes the relations very little.

Two main findings stand out from Table 1: the first is the almost uniform increase in average transaction numbers for the last two decades vs. the initial decade, confirming the national pattern ${ }^{17}$. This can be observed for all indicators, however they are transformed. On average, 2.7 urban buildings are traded per year for every 1,000 inhabitants of Spain, increasing from 2.6 in the first period to 2.8 for the last two decades.

The second finding is the confirmation of the increasing importance of the six provinces with the largest cities, even if the numbers are adjusted by population size. In these provinces, on average, 3.2 buildings were traded per 1,000 inhabitants in the first decade of our sample, increasing to 3.8 in the second and 3.7 in the last sub-period. Interestingly, the difference between the six provinces with largest cities and the Spanish mean increases over time. Most striking is the difference, both in levels and in trends of the provinces with small urban and total populations, which show much lower total, per head and per floor transaction numbers, which are also decline sharply over time. This is additional evidence of the impact of the ruralurban transition on regional real estate markets.

To put the number of transactions in perspective, Table 2 gives an idea of the stock of housing in the population and building census years 1900, 1910, 1920 and 1930. We observe a constant increase in the number of buildings from 4.5 to 5.4 million, although the pace of this increase seems to be slightly below that of population growth, as the number of buildings and floors per person decreases slightly over time, despite slightly increasing number of floors per building (from 1.82 to 1.86 in the national average).

In accordance with the concentration of the numbers of transactions we also observe a concentration process in the total number of buildings: While in 190013.6 per cent of the buildings were located in the six provinces with

17 The one exception is the largely rural region of Northern Castile, where transaction numbers decline in all provinces after the first decade. 
TABLE 2

THE EVOLUTION OF THE HOUSING STOCK IN CENSUS YEARS, 1900-30

\begin{tabular}{|c|c|c|c|c|}
\hline & 1900 & 1910 & 1920 & 1930 \\
\hline & (1) & (2) & (3) & (4) \\
\hline \multicolumn{5}{|l|}{ (a) Housing stock in census years } \\
\hline Andalucia & 743,682 & 774,874 & 820,193 & 868,237 \\
\hline Mediterranean & 928,153 & $1,005,744$ & $1,060,518$ & $1,212,268$ \\
\hline Ebro Valley & 561,300 & 570,367 & 585,810 & 607,055 \\
\hline Northern Castile & 791,949 & 821,833 & 839,056 & 867,528 \\
\hline Southern Castile & 671,376 & 738,372 & 794,315 & 899,669 \\
\hline North & 828,756 & 881,554 & 915,600 & 973,006 \\
\hline Spain & $4,525,216$ & $4,792,744$ & $5,015,492$ & $5,427,763$ \\
\hline Six provinces largest cities & 613,300 & 659,348 & 706,402 & 827,167 \\
\hline Six provinces least urban population & 496,782 & 516,613 & 528,081 & 557,967 \\
\hline Six provinces lowest population & 319,036 & 325,707 & 330,589 & 335,551 \\
\hline \multicolumn{5}{|c|}{ (b) Housing stock per 1,000 inhabitants in census years } \\
\hline Andalucia & 209 & 202 & 196 & 188 \\
\hline Mediterranean & 223 & 226 & 223 & 225 \\
\hline Ebro Valley & 315 & 311 & 302 & 303 \\
\hline Northern Castile & 344 & 348 & 357 & 349 \\
\hline Southern Castile & 221 & 217 & 211 & 205 \\
\hline North & 245 & 243 & 236 & 233 \\
\hline Spain & 248 & 246 & 240 & 235 \\
\hline Six provinces largest cities & 170 & 167 & 156 & 148 \\
\hline Six provinces least urban population & 364 & 363 & 368 & 371 \\
\hline Six provinces lowest population & 323 & 321 & 329 & 318 \\
\hline \multicolumn{5}{|c|}{ (c) Floors per 1,000 inhabitants in census years } \\
\hline Andalucia & 347 & 344 & 333 & 321 \\
\hline Mediterranean & 454 & 461 & 451 & 445 \\
\hline Ebro Valley & 680 & 678 & 659 & 669 \\
\hline Northern Castile & 576 & 598 & 622 & 614 \\
\hline Southern Castile & 376 & 374 & 363 & 351 \\
\hline North & 421 & 441 & 433 & 430 \\
\hline Spain & 451 & 456 & 447 & 437 \\
\hline
\end{tabular}


TABLE 2 (Cont.)

\begin{tabular}{|l|l|l|l|l|}
\hline Six provinces largest cities & 354 & 350 & 326 & 301 \\
Six provinces least urban population & 636 & 650 & 662 & 671 \\
Six provinces lowest population & 641 & 660 & 675 & 659 \\
\hline
\end{tabular}

Notes and sources: See Table 1.

the largest cities, in 1930 this share was 15.2 per cent. The share of buildings in the least populated cities, on the other hand, decreased from 7.1 to 6.2 per cent, despite slightly increasing absolute numbers. While the housing stock increased by an average of 0.6 per cent per year in Spain, it increased by 1.0 per cent per year in the provinces with the largest cities, but only by $<0.2$ per cent in the least populated provinces.

\section{THE HEDONIC INDEX OF SPANISH HOUSING MARKETS}

To trace the evolution of urban real estate prices over our 30-year period, it is advisable to keep both prices and quality of houses, that is, urban nonfarm property, constant over time. Especially between 1916 and 1920, Spain experienced an inflation spurt that also affected house prices, so that we have to deflate housing prices to evaluate the real evolution of urban real estate prices in comparison with the general price level. In addition, like many other goods, houses differ in characteristics and quality, and the average quality of housing probably changed during the substantive urbanisation of the first 30 years of the $20^{\text {th }}$ century. In other words, the characteristics of the basket of dwellings put onto the market varied from one period to another.

For both reasons, inflation and quality changes, indices based on mean observed trading prices are not representative for the population of dwellings, and might not be comparable over time or between places ${ }^{18}$. While inflationadjustment is a standard practice in economic history, the quality-adjustment undertaken here might require a short introduction to the literature on hedonic, that is, quality-adjusted, price indices. The idea behind these indices is to estimate econometrically how the price of a product can be related to the product's characteristics to be able to control for changes in the average observed variety and price. The estimated coefficients from this «hedonic regression» are then used to calculate price indices for a constant-quality «counterfactual» version of the product. Probably the most prominent example of the use of hedonic price

18 Alternative indices based on median transaction prices are less sensitive to extremely observed transactions, but still subject to selectivity bias, as the average quality of dwellings sold may change over time (Gouriéroux and Laferrère 2009). 
adjustments in the calculation of price indices is from the rapidly advancing technologies of the information and communication technology sector (Berndt and Griliches 1993; Triplett 2006). When constructing hedonic price indices, one important distinction faced by the researcher is that between changing characteristics of the good in question and variables explaining demand and supply for the good in question. For the construction of the hedonic index, only characteristics are to be taken into account to construct an artificial reference variety of the good, «Variety Without Qualities» ${ }^{19}$, whose main purpose is also to incorporate constant qualities over time. Supply and demand variables might then in a second step, not undertaken here, explain price differences and movements of that reference variety across space and time.

For the computation of housing price indices, the advantages of the hedonic methodology have long been recognised by the literature (Case et al. 1991; Diewert 2006). Ideally, one should observe a representative sample of all individual transactions and their characteristics relevant for the hedonic method. Unfortunately, this is impossible for the distant past given that sources offer only average prices of houses sold, while standard/average characteristics and quality can only be observed for the entire sample/stock of dwellings. Therefore, to be able to make hedonic adjustments, we have to assume that our dwellings are in some way a representative sample of the whole population. However, since it is possible that buyers reacted to soaring prices by demanding lower qualities (and vice versa for decreasing prices), our indices might overestimate upward and downward movements in dwelling prices but not their long-run tendency.

Our hedonic price index was calculated using three successive steps. First we checked the original data on nominal sales volumes and sales numbers at the provincial level for consistency and calculated average nominal prices for each province and year using the value and number of sales for urban nonfarm properties (fincas urbanas) for which a price was actually paid, that is, excluding inheritance or other non-sale property transfers (Fincas enajenadas por actos o contratos en que media precio). In the process, we found that for many provinces the data for 1927 are completely inconsistent with other years, and we therefore excluded $i^{20}$. For the presentation of the index we interpolated data for this year and for 1909 and 1910, for which no sales

${ }^{19}$ We borrow this term from the title of Robert Musil's novel «The Man Without Qualities» (Der Mann ohne Eigenschaften, 1930-1943).

${ }^{20}$ For example, according to our source the number of sales in the province of Guadalajara increased from 140 in 1926 to 3,901 in 1927, and then fell back to 119, the long-run average (excluding 1927) being 143 sales per year. In Soria, the number of sales was reported as 3,571, with the long-run average (excluding 1927) being 82 sales per year. In contrast, in Valencia, the number of sales fell from 7,672 in 1926 to 977 in 1927, being 5,724 in 1928, and in the province of Oviedo sales were reported as 100, against a long-run average of (excluding 1927) 1,184 sales per year. Many more examples could be quoted. Since at the national level the figures seem relatively consistent with former and later years $(68,228$ sales against 63,553 in 1926 and 67,028 in 1928), we suppose that figures for different provinces have been reported for others, probably due to typographic 
records have been published. In the preparation of the hedonic index, however, the values for these years have been treated as missing. We also corrected other values from the original publication because the figures were highly implausible, that is, they diverged by more than two standard deviations from the arithmetic mean of real prices for the whole period ${ }^{21}$.

The average nominal prices per province calculated are then converted into average real PPP prices (Barcelona $1910=100$ ) using the provincespecific urban consumer price indices from Rosés and Sánchez-Alonso (2004). This consumer price index is comprehensive since it collects information on food, textiles, housing equipment, fuel prices and housing rents ${ }^{22}$. As we will see later, this correction accounts for the bulk of the difference between the reported nominal and hedonic real indices.

However, since we expect important differences between the characteristics of the average property sold in provinces with low levels of urbanisation and industrialisation (such as Soria, Teruel or Lugo) and those containing the large and industrialising Spanish metropolitan areas (such as Madrid, Barcelona or Biscay with its urban cluster around Bilbao), we have to correct the prices not just for PPP differences, but also for different characteristics of the properties themselves, and therefore use hedonic price adjustment. We use a two-step procedure, departing from the idea that the price of an urban property is actually a function of the bundle of prices for each relevant feature of a property, for example, its location, size (number of floors), age, etc. The first step of our hedonic correction therefore is the «hedonic regression" of the price of urban properties on measures of the different characteristics, so that the effects of each characteristic on the final price are estimates of the price elasticities to changes in each characteristic. The coefficients of this regression are then used to calculate the price of a reference property in each province, which has baseline characteristics. This means the properties sold in different provinces become comparable. To this end, we follow the approach of Gouriéroux and Laferrère (2009), who calculate hedonic indexes for real estate property in

\section{(F'note continued)}

confusion, and this to an extent that makes it impossible to reassign the sales numbers and values to the correct provinces.

21 This resulted in 33 corrections of values for the time period 1904-1931, mostly in small provinces. The maximum number of corrections per province is 3 for Guipuscoa $(1924,1925,1929)$ and Navarre $(1904,1919,1929)$. We abstained from corrections of real prices between 1932 and 1934, except for the province of Burgos in 1932 and Seville in 1934, where we see implausible movements in the value of property. Real prices increase from 1,934 to 6,550 pesetas per unit in Burgos 1932, and fall from 5,783 to 730 pesetas per property in Seville in 1934. After correcting a typographic error in the original source (one digit missing) we obtain a real average value of 6,284. In Burgos, we linearly interpolated the price to 2,189 .

22 One might argue that some of our urban (non-farm) properties are located in rural regions (especially in the less urbanised provinces) and therefore their price should be deflated by a rural CPI. While in theory this might be true, in the reality of early $20^{\text {th }}$-century Spain, rural and urban CPIs at the provincial level were highly correlated and therefore the problem is, in practice, less relevant (see Carmona and Rosés 2012 for average farm prices deflated by rural CPIs). 
modern-day France based on information about the characteristics of individual properties and their sales from French notaries. However, we do not have information on individual buildings, but just on average prices and characteristics per province, so we have to modify their approach accordingly.

Following Gouriéroux and Laferrère (2009), we assume age, number of floors and location (which province, average degree of agglomeration) to be the most important characteristics. We first reconstruct the average age and - to account for potential discontinuities between zero year old «new» buildings and 1-year-old «old» buildings - the average share of new buildings to account for average vintage per province, the average number of floors, and the average share of isolated buildings (those located in "settlements» with five or fewer buildings) per province and year as explained in the following. Our approach allows us to correct for some of the shortcomings of the Yearbook's price data, for example, the lack of distinction between new and second-hand properties. Nevertheless, it is necessarily based on the assumption that in each year the characteristics of the urban properties sold reflect the average characteristics of the existing stock of buildings, which changes only slowly between census years, thereby making our hedonic adjustments rather conservative. It is likely that further quality adjustments of prices (e.g. if we assume that all new houses were traded during the year) would result in even lower price increases.

For the reconstruction of average age per province we use information on the increase of the stock of buildings between 1900, 1910, 1920 and 1930, for which the inhabited buildings census provides the number of buildings per province, as presented in Table 2. Due to the lack of provincial data before 1900 , we assume a uniform initial age distribution of buildings across provinces, which we reconstruct from the figures on gross capital formation in dwellings for the whole of Spain in Prados de la Escosura (2003, table A7-2A), assuming that the share of buildings age 0-70 in 1900 is represented by the relative gross capital formation in each year between 1855 and 1900 . The stock of buildings in 1855 that emerges from re-extrapolating the stock in 1855 with the gross capital formation growth rates is assumed to have been built uniformly distributed with the share of $(1 / 25) \times$ stock of 1856 between 1830 and 1855 in each year. The assumption of 70 years service age per building is taken from Prados de la Escosura and Rosés (2010). With this data, we reconstruct by province how many of the existing buildings were built in each year between 1830 and 1934. Since before 1900 we have no information at the provincial level, before that year we assume a uniform distribution all over Spain, with 1.07 per cent of all buildings being from 1830 (and therefore 70 years old in 1900) as well as from each of the years before 1856. From 1856 to 1900 , we use the shares the gross capital formation by Prados de la Escosura mentioned above; so, for example, 2.2 per cent of all 1900 buildings are assumed to be from 1866 ( 34 years old), when gross capital formation was very strong, but only 0.8 per cent from the following year (33 years old) when building activity slackened. Multiplying the 
shares of each year by the age of buildings it represents leads us to an average age of 31.1 years in 1900 for all buildings in Spain.

From there, we extrapolate the stock in each year with the compound growth rate per province between adjacent census years. The share of new buildings is then defined as the net number of new buildings in each year (increases in the stock following from intercensus growth rates) plus the number of buildings of the initial (1900) distribution that «retire» as they become older than 70 years (e.g. the 1.07 per cent of all buildings assumed to be constructed in 1830 in the year 1901). The average age is calculated from the initial distribution and the share of new buildings after 1900 as the sample moves on. Since after 1900 we have data on province level growth rates of the housing stock, now the average age per building can vary between provinces. We can see that in 1904 the average age is still grouped quite closely around our uniform initial estimate of 31.1 years in 1900 for all provinces, with a minimum of 30.2 for the province of Oviedo (Asturias) and a maximum of 32.8 for the province of Lerida ${ }^{23}$. In 1934, the minimum is 24.5 years for Madrid and the maximum 37.1 for Cadiz. Since our hedonic regressions include fixed effects per province, what we are measuring here is the increasing deviation from the mean, not so much the absolute average age, which is of course much more subject to our assumptions. Since the relation between average age and price might not be $(\log )$ linear, we also add the average share of new buildings per year to our regressions, calculated as the ratio of new buildings as stated above to the total stock in each province-year.

The second characteristic, the average number of floors, can also be calculated from the information in the inhabited building censuses, which state how many buildings had one, two or three and more floors. "More than 3 floors» is refined to three, four and five and more in the 1930 census. We use the average of the latter (assuming « 5 and more» to be five) to calculate the province-specific meaning of « 3 and more». Between census years we interpolate with compound growth rates. In 1904, the (unweighted) average number of floors is 1.88 per building, with a maximum of 2.82 for Guipuscoa and a minimum of 1.32 for Huelva ${ }^{24}$. In 1934, the minimum was 1.37 for Huelva and the maximum 2.92 for Guipuscoa.

In the same way, we also calculate the average share of isolated inhabited buildings (according to the censuses, these are located in groups of five or fewer buildings) as a proxy for the urban density, and hence likely positive agglomeration effects in a province. On average, this share is lowest in Salamanca (3.8 per cent) and highest in Guipuscoa (46.7 per cent), clearly

23 This means that the number of buildings in Lerida between 1900 and 1910 increased by less than the part of the stock calculated to be withdrawn between these years (those constructed between 1830 and 1840): in these years 440 houses were built on average per year in this province, while 968 would exit our calculations (and by assumption cease to exist) per year.

${ }^{24}$ Actually, the lowest value was 1.1 to 1.2 for the Canary Islands, which have been excluded from our indices because of lack of CPI. 
showing different settlement patterns across Spain. We use this variable, since the building census does not distinguish clearly between urban and non-urban areas, and only gives the share of «isolated» buildings. We take this as an approximation of the likelihood that the average non-farm property in a province is not located in an important metropolis, but in a rather small place. Please note that we use this as a proxy for an average characteristic of the building, not as an explanatory variable of its price, as for example population density might be. Also, the share of «isolated» buildings is not necessarily highly correlated with population density, but with the relative agglomeration of buildings in space.

As a second correction for the location effect, we include provincespecific fixed effects into our regression, controlling for all kinds of differences that are fixed over time. This is mainly econometrically motivated to avoid omitted variable bias in our estimations. It also implies that our main source of variation and basis of identification for the coefficients is not variation between places, but for the same places over time. Remember that correcting for intertemporal variations in characteristics is the main motivation for calculating hedonic prices. Normally, and throughout our paper, we are not comparing the levels of prices over provinces, but the relative evolution of price indices with the same base year over time.

With these variables we estimate a frequency-weighted panel GLS regression; the weights are average number of sales per province over the whole period, which is a very reasonable choice given that the prices we have are average prices for that number of buildings (the panels estimator we use requires the use of constant frequency weights over time, therefore the average). The results are reported in Table 3.

All coefficients are precisely estimated and show the expected signs: prices are higher for provinces having, on average, buildings with more floors, more recently constructed buildings, buildings that are not isolated and a larger share of new buildings. To give an insight into the implications for the construction of the hedonic index for two of the main variables, numbers of floors and age, the average house in Spain (excluding the Canary Islands) had 1.86 floors in 1910 and was, according to our calculations (weighted with the population of buildings according to the 1910 census), 31.8 years old. Adding one more floor to the average building (increasing number of floors by 54 per cent) would, according to our results, increase the real price by 66 per cent and one additional year of age (ageing the average building by 3.1 per cent) would reduce the real price by 1.4 per cent. Therefore, if the average age, number of floors or the other characteristics change over time, we will take that into account. The hedonic index will therefore only increase or decrease if real prices change more than the changes «statistically justified» by changes in average characteristics (or if nominal prices change more than the average cost of living index plus the change in average characteristics). 
TABLE 3

ESTIMATION OF DETERMINANTS OF THE HEDONIC INDEX

\begin{tabular}{|l|c|c|c|c|}
\hline & Coefficient & SE & $\boldsymbol{T}$ & $\boldsymbol{P}>\mid \boldsymbol{t} \boldsymbol{|}$ \\
\hline & $\mathbf{( 1 )}$ & $\mathbf{( 2 )}$ & $\mathbf{( 3 )}$ & $\mathbf{( 4 )}$ \\
\hline Ln(floors) & 1.2308 & 0.0156 & 77.58 & 0.000 \\
Ln(age) & -0.4376 & 0.0043 & -99.85 & 0.000 \\
Share isolated & -1.6145 & 0.0108 & -149.73 & 0.000 \\
Share new & 8.6077 & 0.0482 & 178.51 & 0.000 \\
Constant & 8.7445 & 0.0482 & 178.51 & 0.000 \\
F-test & 17450.24 & & & 0.000 \\
$R^{2}$ overall & 0.3051 & & & \\
\hline
\end{tabular}

Notes: We estimate the equation [1]. The method of estimations is GLS with fixed effects. Regression is weighted by the mean number of houses sold. The number of observation is 1,344 (48 groups $\times 28$ years).

Sources: See Figure 1.

Technically, based on our results in Table 3, following Gouriéroux and Laferrère $\left(2009\right.$, p. 210), we calculate the $\log$ hedonic price $\tilde{p}_{j, t}$ as the difference between the observed prices $p_{j, t}$ and the characteristics weighted by their coefficients. We assume that the weights are stable over time. This is

$$
\ln \left(\tilde{p}_{j, t}\right) \cong \ln \left(p_{j, t}\right)-\sum_{k=1}^{K} \hat{\beta}_{k, s} X_{k, j, t}=\ln \left(\frac{p_{j, t}}{\operatorname{EXP}\left(\sum_{k=1}^{K} \hat{\beta}_{k, s} X_{k, j, t}\right)}\right)
$$

Or in our case

$\ln ($ hedonic price $)=\ln [($ real average price $) /(\exp (1.230846 \ln$ (floor)

$$
\begin{aligned}
& +-0.4347637 \ln (\text { age })+-1.61455(\text { share isolated }) \\
& +8.607792(\text { sharenew })))]
\end{aligned}
$$

The hedonic price index then is calculated for every province $j$ by the difference of the logs $I t / 1904, j=\exp ($ lnhedonicreal $t, j-\operatorname{lnh}$ edonicreal 1904, $j$ ) and rebased to $1904=100$. From these a Törnquist index, an approximation of the Divisia index for the whole of Spain (excluding the Canary Islands) is constructed, where the shares of expenditure (real value of total sales per province) are used as weights (see Hulten 2008). These could be compared with Divisia indices of the nominal and PPP adjusted real price indices per province $^{25}$.

${ }^{25}$ We also calculate such indices for the provinces with the six largest cities of Spain (Madrid, Barcelona, Seville, Valencia, Biscay with Bilbao and Saragossa), and for the six macro-regions as defined in Rosés and Sánchez-Alonso (2004): Andalusia (Almeria, Cadiz, Cordoba, Granada, Huelva, 
As a consistency check, we also calculated the hedonic index, with the same basis data for the provincial average properties, for transactions that were not made by contracts with a sales price (Fincas enajenadas por actos $O$ contratos en que no media precio). These are mainly bequests and other sorts of non-market transfers. Here, we excluded the share of new urban properties since there is no reason to assume that they play the same role in this sort of transaction as in «normal» market transactions. The hedonic regression in this case, again with precisely estimated coefficients and expected signs, leads to the following equation:

$$
\begin{aligned}
\ln (\text { hedonic price })= & \ln [(\text { real average price }) /(\exp (0.4755128 \ln (\text { floor }) \\
& +-2.478677 \ln (\text { age })+-2.297104(\text { share isolated })))]
\end{aligned}
$$

Figure A1 shows that the real and hedonic prices of these non-market transactions actually follow a similar pattern to the market transactions, with the exception of the late-/post-war inflation spurt, when real values dropped for non-market transactions, while they increased for market transactions. In both cases, the main adjustment of prices does not follow from the hedonic quality-adjustment, but just from converting nominal into real prices, although the hedonic adjustment in the case of non-market transactions seems to be more pronounced, probably because of the slightly different formula we applied.

Please note that hedonic prices are normally presented as indices (Diewert 2006, pp. 103-104), since their construction involves correcting for the individual characteristics, so that the result is the creation of a "Building Without Qualities», those being constant over time, but not meaningful in terms of imagining the actual hedonic reference building. For a house in Barcelona in 1910, which is the place and period the PPAs we use are benchmarked onto, the real price would be 10,566 pesetas, while the hedonic price would be 18,103 pesetas. The observation that the hedonic price is higher than the real price is due to the sum of the adjustments above and the resulting artificial characteristics of the "constant no qualities reference building». Note that it does not have any meaningful implication for price levels, living standards, etc. The lowest price in that year would be 1,072 «Barcelona pesetas» per house in Almería in real terms, which would increase to 4,008 «hedonic Barcelona pesetas». Buildings in Barcelona in

\footnotetext{
(F'note continued)

Jaen, Malaga and Seville), Mediterranean (Gerona, Barcelona, Tarragona, Castellon, Valencia, Alicante, Murcia and Balearic Islands), Ebro Valley (Lerida, Saragossa, Huesca, Teruel, Logrono, Alava and Navarre), Southern Castile (Caceres, Badajoz, Albacete, Ciudad Real, Cuenca, Guadalajara, Madrid and Toledo), Northern Castile (Salamanca, Zamora, Leon, Valladolid, Palencia, Burgos, Soria, Segovia and Avila) and North (Corunna, Pontevedra, Lugo, Orense, Asturias, Santander, Guipuscoa and Biscay).
} 
TABLE 4

AVERAGE LEVELS OF REAL AND HEDONIC PRICES, 1904-34

\begin{tabular}{|l|c|c|c|}
\hline & $\begin{array}{c}\text { Average price } \\
\text { sales (real) }\end{array}$ & $\begin{array}{c}\text { Average price non-sales } \\
\text { transactions (real) }\end{array}$ & $\begin{array}{c}\text { Average price } \\
\text { sales, (hedonic) }\end{array}$ \\
\hline Andalucia & 2,536 & 4,222 & 6,705 \\
Mediterranean & 4,128 & 4,401 & 7,557 \\
Ebro Valley & 2,857 & 2,407 & 6,388 \\
Northern Castile & 2,010 & 2,202 & 4,786 \\
Southern Castile & 5,490 & 6,577 & 10,060 \\
North & 8,184 & 9,548 & 16,666 \\
Spain & 3,971 & 4,679 & 8,082 \\
Six provinces largest & 7,419 & 8,499 & 12,992 \\
$\quad$ cities & 2,062 & 2,279 & 5,031 \\
Six provinces least & & & \\
$\quad$ urban population & 2,857 & 2,555 & 5,813 \\
Six provinces lowest & & & \\
population & \multicolumn{2}{|l}{}
\end{tabular}

Notes and sources: prices in PPP-adjusted «Barcelona 1910 pesetas», weighted by average number of sales/non-sales transactions per province.

that year have on average 2.3 floors, are 30.6 years old, 1.4 per cent of them are new, and 13.6 per cent are isolated, while in Almeria the average building has 1.4 floors, is 33.0 years old, 0.6 per cent new and 15 per cent isolated. This example shows that in absolute terms, the hedonic adjustment is increasing the value of our buildings by about 7,500 pesetas in Barcelona and by close to 3,000 pesetas in Almería. Table 4 gives a more detailed overview of price levels and also compares real prices in sales transactions to those where no price was reported for $1904-1934^{26}$.

In this context, it is worthwhile noting that we have used the fixed effects only to estimate the coefficients in the first stage, not to construct the hedonic prices using those coefficients. If we had done so, we would have assumed that systematic differences in the price level apart from the characteristics we control for, between Barcelona and Almería would be due to unobserved characteristics of the (average) buildings in both places. While there might be such differences, most of the systematic difference should be due to factors treated by economic geography, such as different amenities or productivity of labour due to scale effects or economic structure which have little to do with the characteristics of buildings and much more to

26 Table does not report hedonic price levels for non-price transactions, since the index is constructed differently (no share new included) its values in levels are much higher. 
do with the regional macroeconomic environment. When, we assessing the latter using our new data, we therefore recommend using fixed effects. For the indices presented in the following, this is not of importance, since they set $1910=100$ for all provinces and only report the movement over time for each province or other aggregate.

\section{THE EVOLUTION OF HOUSING PRICES IN SPAIN}

Figure 2 presents the basic information regarding the evolution of Spanish housing prices. As we can observe at once, successive adjustments decrease growth rates of housing prices; that is, nominal housing prices grew faster than real housing prices which in turn rose faster than hedonic adjusted real housing prices. From these results we could infer that overall inflation (CPI) was a major mover in housing prices and that the quality of housing increased over the period. This finding is not surprising given that buildings are built to last a long time (by our assumption, 70 years) and therefore despite animated construction activity, the average characteristics of the stock of buildings change rather slowly, while, on the other hand, we see a major inflation spurt around World War I, with the overall consumer price index doubling between 1912 and 1920 (Prados de la Escosura 2003),

FIGURE 2

THE EVOLUTION OF SPANISH HOUSING PRICES, $1904=100$

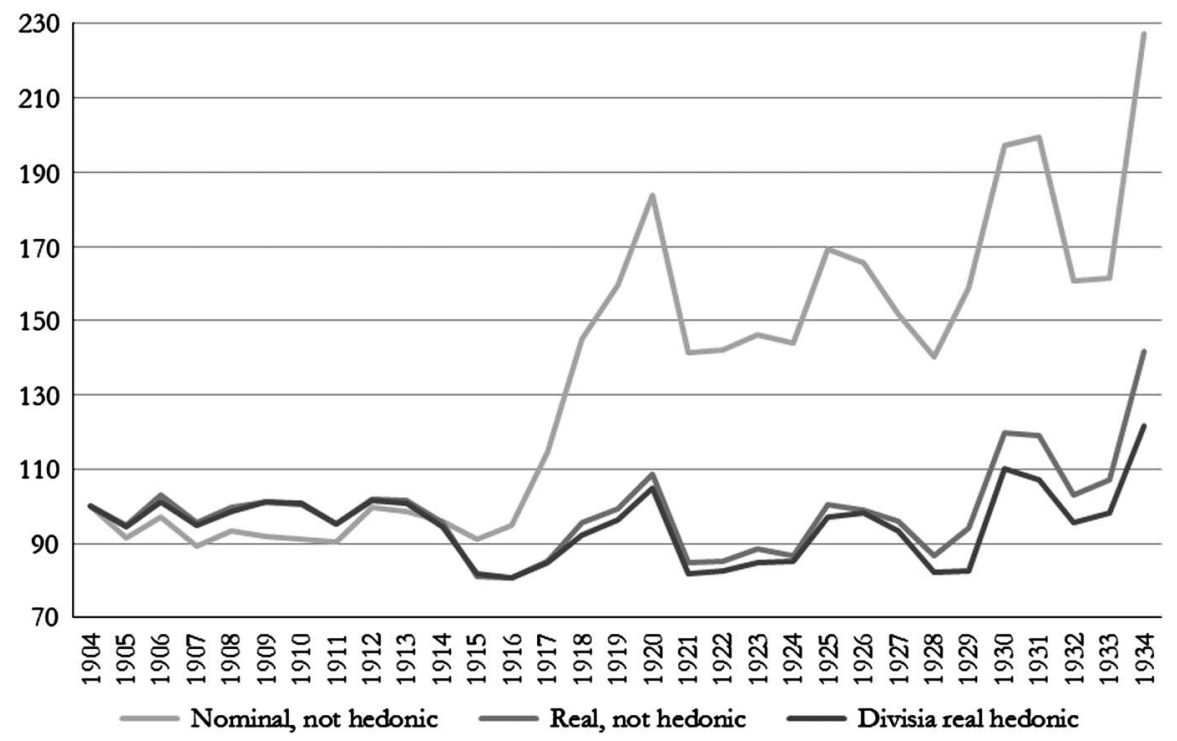

Sources: see Figure 1. 
with most of this increase falling between 1916 and 1920, a period in which we observe a rise in nominal house prices of 96 per cent.

This episode from 1915/1916 actually marks the major break point in the nominal housing index. Until then, inflation in Spain was relatively low (note that Spain did not adhere to the Gold Standard over the entire period) and real housing prices grew faster than consumer prices (real series grew faster than nominal series). In the middle of the War (by 1916), this situation changed and nominal prices grew faster than real prices. Spanish neutrality during the War was not accompanied by an increase in real house prices. The fact is that until 1920 , as the real hedonic price index shows, housing prices did not recover prewar levels. This result is unexpected given that, due to its neutrality, Spain increased its exportations and benefited from the arrival of foreign capital, which was sometimes invested in non-tradable assets like houses.

During the 1920s housing prices decreased again, but they did not actually recover their 1920 level until 1930. Note that the 1920s were a period of rapid growth for the Spanish economy, with unprecedented GDP and TFP growth rates (Prados de la Escosura and Rosés 2009). Furthermore, the quality of housing increased slightly (as shown by the faster growth of the real index in comparison to the hedonic adjusted index). During the first years of the Second Republic (1931-1934), house prices seem to have followed Spain's political cycle: decreased when the left-wing coalition took government, while the contrary holds when right-wing parties replaced it. The impact of the Great Depression, however, is less apparent: housing prices decreased in 1932 and 1933 but less than during the early 1920s.

The presence of huge short-run (yearly) fluctuations in Spanish housing prices from 1904 to 1934 is not obvious. Yearly movements exceeding the 10 per cent of increase or decrease can only be observed in 7 years; that is, 23 per cent of all years. In 1915, 1921, 1928 and 1932 prices decreased by more than 10 per cent while the contrary holds in 1925, 1930 and 1934. The largest increase took place during 1930, when prices increased by 33 per cent, and the largest decrease took place during 1925, when prices fell by 22 per cent. Also, it is difficult to observe any sustained increase in housing prices. Furthermore, if we do not consider the extraordinary year 1934, housing prices were lower in 1933 than in 1904. This suggests that housing was not a very profitable long-run investment in Spain.

A substantial literature has underlined that housing prices tend to grow faster in large cities, where supply restrictions should be more evident. For this reason, we have computed individual indices for the six provinces containing the most populated Spanish cities (Barcelona, Madrid, Biscay, Seville, Valencia and Saragossa). Also, to consider regional differences, we have computed indices for the six Spanish macro-regions (as defined in Rosés and Sánchez-Alonso 2004).

Figure 3 reviews the evolution of the adjusted hedonic index containing the six provinces with the most populated metropolises (hereafter six- 
FIGURE 3

THE EVOLUTION OF HOUSING PRICES IN SPAIN AND ITS SIX PROVINCES CONTAINING THE MOST POPULATED CITIES, $1904=100$

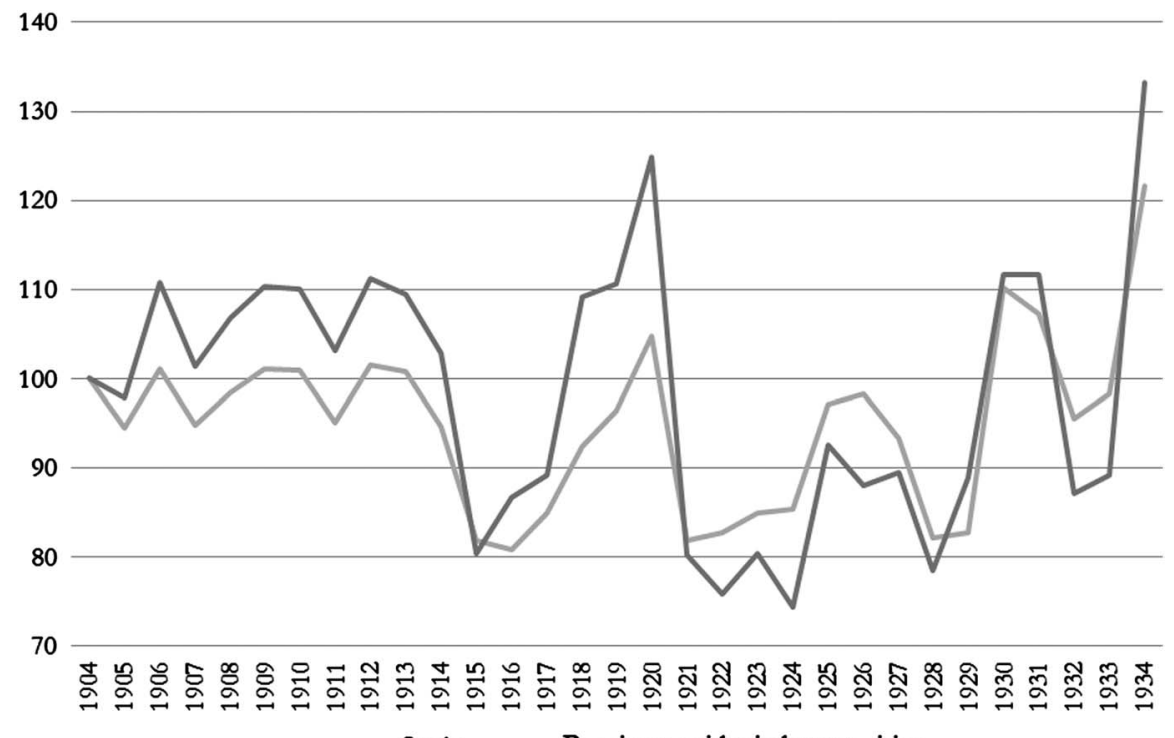

Sources: see Figure 1.

provinces index) and the equivalent Spanish index. Our six-provinces index follows the same pattern as the Spanish index but expansion/depression cycles were more pronounced. Therefore, the downturn during the first years of the First World War in the six-provinces index was more pronounced but so too was the subsequent housing price growth. Again, evidence on dramatic fluctuations is elusive.

Now, we are looking for evidence on dramatic housing increases by looking at individual series for the six-provinces (Figures 4A, 4B, 4C, 4D, 4E and $4 \mathrm{~F}$ ). The hedonic real housing index for the province of Barcelona (Figure 4A) follows the Spanish pattern in the long run but one can observe up to four major episodes of price exuberance in the years 1906, 1913, 19181920 and 1934. In this last year, hedonic housing prices doubled! In Biscay (Figure 4B), not only long-run evolution differs from Spain's, but also one can observe another three major upswings in the years 1906, 1908 and 19191920. Interestingly, housing prices decreased significantly after the 1929 crisis; perhaps, this was due to the fact that Bilbao was a major mineral export and shipping centre and, hence, closely connected with the fortune of markets abroad. Also, as the region was the seat of major steel and 
investment goods factories, it was particularly hit by the second wave of the crisis after $1931^{27}$. In the case of Madrid (Figure 4C), the synchronisation with Spanish housing prices is more evident and price increases were much less pronounced than in the previously mentioned two provinces. Again, we observe several major episodes of price expansion in 1918-1920, 1925 and 1930-1931, and also an enormous slump, when housing prices practically halved, in 1933. The price evolution of Saragossa (Figure 4D) shows plenty of ups and downs. At first sight, we can observe major upswings in 1906, 1920, 1926 and 1930; and a period of sustained growth in housing prices from 1910 to 1916. It might be worth noting that changes in Spanish trade policy benefited the city of Saragossa, which industrialised over this period. The province of Seville (Figure 4E) also experienced several episodes of exceptional increases in housing prices: 1912, 1930 and 1933-1934. Finally, in the province of Valencia (Figure 4F), one can observe several episodes of explosive growth in the years 1907, 1911, 1931 and 1933.

Figures $5 \mathrm{~A}-5 \mathrm{~F}$ review the evolution of housing prices in the six Spanish macro-regions compared with Spain. Synchronisation with Spain's overall price evolution is evident in the Mediterranean region (Figure 5B), and Southern Castile (Figure 5D). In contrast, in the other four regions housing prices were apparently much less coordinated with the Spanish average. In Andalusia (Figure 5A), housing prices decreased during First World War (while the contrary holds for Spain) and price movements were more marked from 1925 onwards. In the Ebro Valley (Figure 5C), prices grew faster than in the rest of the country and peaks were much more abundant and pronounced. Northern Castile (Figure 5E) experienced an enormous increase in house prices in 1930 when prices tripled! Finally, the North region (Figure 5F) followed the Spanish pattern until 1929 and then experienced a severe downturn in housing prices (at the same time, the average price for all of Spain grew).

A simple comparison of Figures 1 and 2 offers relevant information on how housing markets worked in Spain. We note that increases in the number of houses traded did not translate into large movements in the hedonicadjusted housing prices. In particular, during the 1920s, the number of transactions rapidly expanded, but housing prices remained stable in Spain and its six most populated provinces.

In light of the rather dramatic changes that occurred during the urban-rural transition process throughout this period (see introduction), we are quite surprised by the housing market's price stability and rapid adjustments to the growing number of transactions. By and large, the market operated smoothly (i.e. increasing demand was met by increasing supply, and prices remained stable over the medium-term horizon of this paper). To make sense of our findings, we must examine in greater detail the determinants of the market's evolution, but this task goes well beyond the limited objectives of this article.

${ }^{27}$ We are very grateful to a referee for pointing this out. 


\section{FIGURE 4}

EVOLUTION OF HOUSING PRICES, 1904-34: (A) BARCELONA VS. SPAIN;

(B) BISCAY VS. SPAIN; (C) MADRID VS. SPAIN; (D) SARAGOSSA VS. SPAIN;

(E) SEVILLE VS. SPAIN; (F) VALENCIA VS. SPAIN.
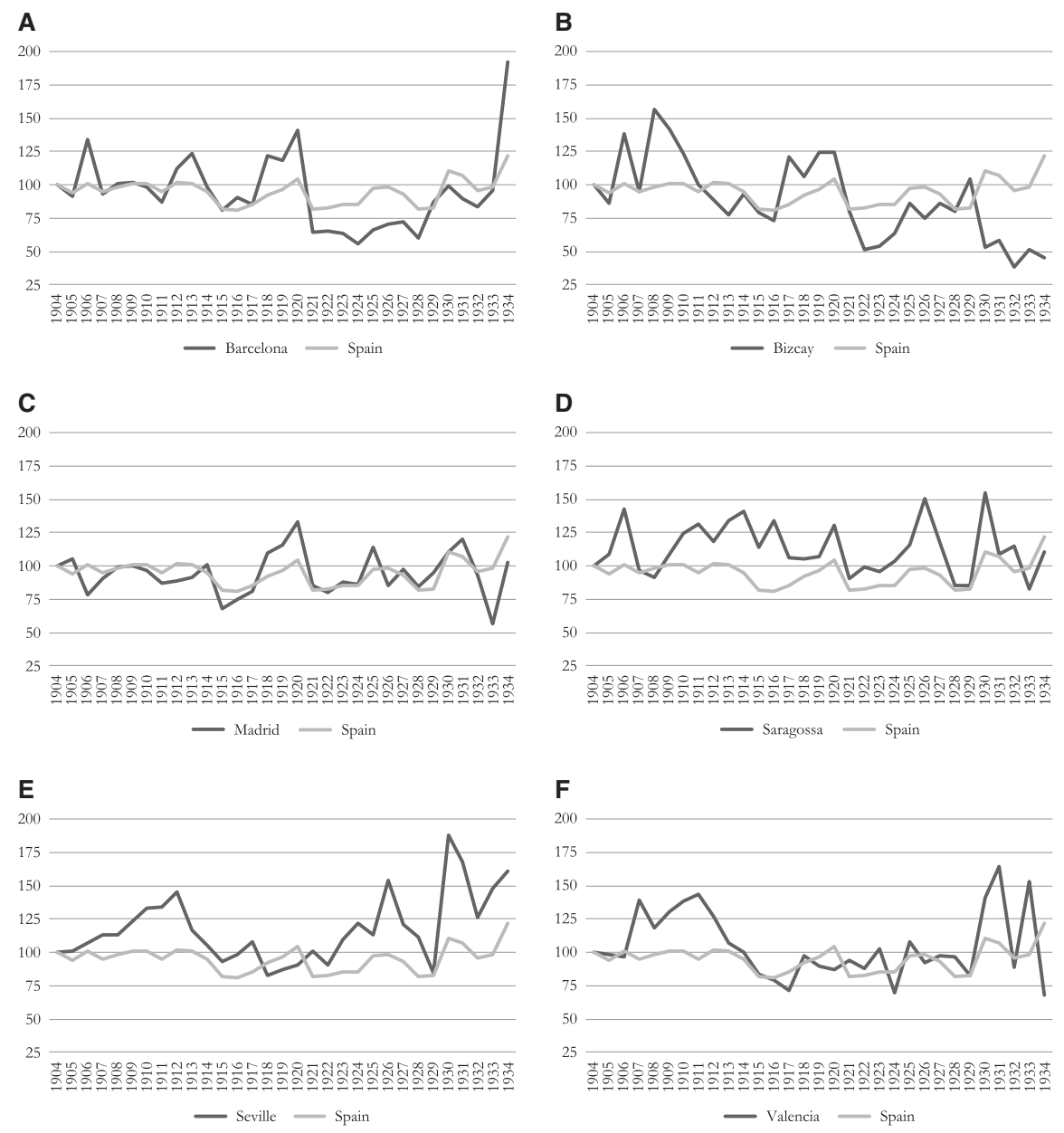

Notes: see text. Sources: see Figure. 1.

\section{CONCLUSIONS}

The purpose of this paper has been to analyse the basic facts (prices and quantities) regarding the evolution of Spanish housing markets during the first third of the $20^{\text {th }}$ century using a new database. The analysis of 
FIGURE 5

EVOLUTION OF HOUSING PRICES, 1904-34: (A) ANDALUSIA VS. SPAIN;

(B) MEDITERRANEAN REGION VS. SPAIN; (C) EBRO VALLEY VS. SPAIN;

(D) SOUTHERN CASTILE VS. SPAIN; (E) NORTHERN CASTILE VS. SPAIN;

(F) NORTH REGION VS. SPAIN.

A

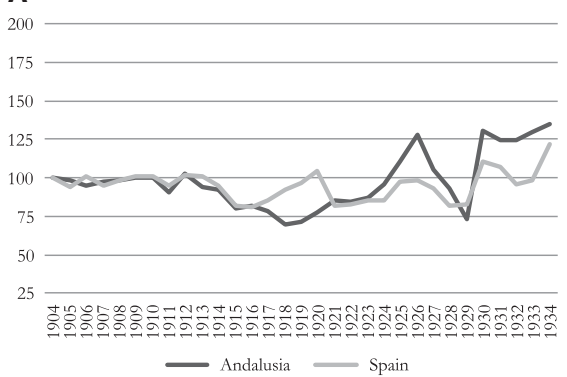

C

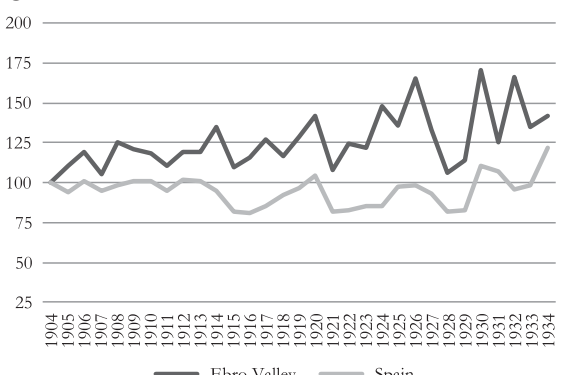

\section{E}

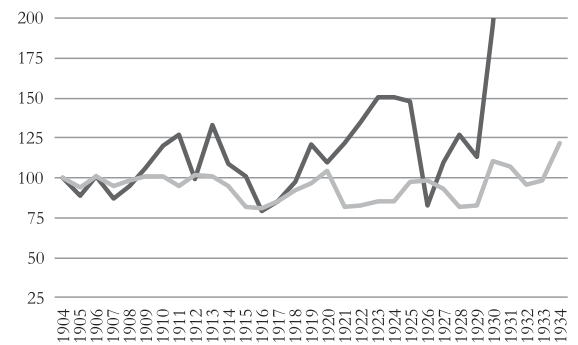

Northern Castile

\section{B}

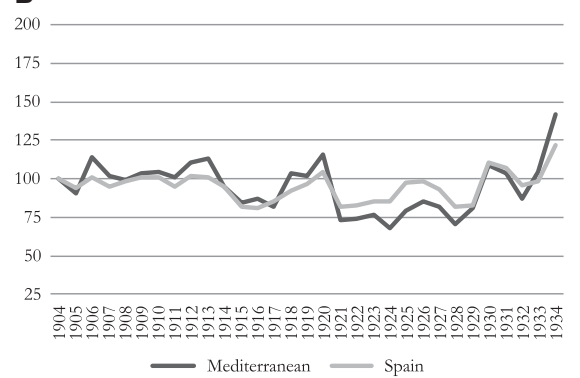

D

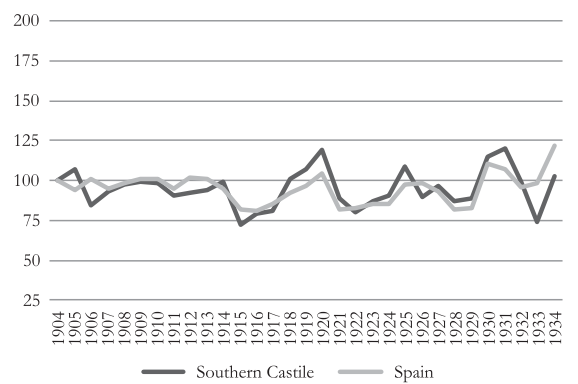

$\mathbf{F}$

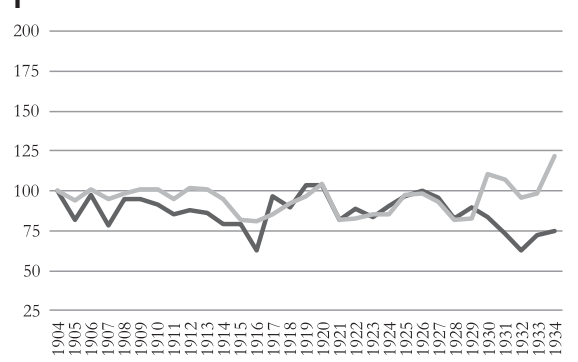

Notes: see text. In Northern Castile, values are above 200 after 1930: 1931: 320, 1932: 274, 1933: 252, 1934 309. Sources: see Figure 1.

housing prices has been carried out by calculating real prices and estimating hedonic prices indices, and a subsequent exploratory analysis of these new indices. 
This analysis has produced three main findings. First, Spanish housing transactions increased over the period considered in this study. However, housing transactions were more numerous in the provinces with the largest cities than in the rest of the country. This is, indeed, an indication that housing markets were more active where urban population gained momentum.

Second, at the aggregate level, real Spanish housing prices did not experience a major upsurge over this period (prices were lower in 1933 than in 1904) despite major increases in population and urbanisation rates. Therefore, housing was not a very profitable investment in Spain during the period.

Third, this pattern is replicated in most Spanish regions. Even in the most densely populated and urbanised provinces, increases in real housing prices were, at best, modest. In sum, the housing market appears not to have damaged the reallocation of labour from rural locations to cities, and from declining to expanding regions. Nevertheless, the regional dimension of house price changes and their economic implications surely merits attention and should be an object of further study.

Fourth, and related to the latter point, we would like to highlight that long-run price stability does not preclude the existence of bubbles in regional or provincial housing markets. What we have already demonstrated is that, if bubbles existed, they did not last long. However, our method is not designed for analysing and detecting housing bubbles. If one looks in detail at graphs 4 and 5, the presence of unexpected and short-lived upsurges in housing prices is evident at the disaggregate level. To detect bubbles, we should develop an econometric method capable of separating price fundamentals from non-fundamentals. In consequence, future research is required to inform us whether this relatively abundant presence of regional booms in housing prices was due to irrational episodes.

\section{REFERENCES}

Academia De Ciencias Morales Y Políticas (1861): «Informe que la Real Academia de Ciencias Morales y Politicas eleva al Gobierno sobre la reforma de las Leyes de Inquilinato y los medios de contener el aumento desproporcionado de los alquileres de edificios», In: Memorias de la Real Academia de Ciencias Morales y Políticas. Madrid, Vol. I, pp. 265-328.

Anuario de la Dirección General de los Registros Civiles y de la Propiedad y del Notariado. 1905-1935. Madrid: Ministerio de Gracia y Justicia, several years.

Alchian, A. A., and Demsetz, H. (1973): «The Property Rights Paradigm». Journal of Economic History 33 (1), pp. 16-27.

Ayllón, M. C.; Lacasta, P., and Tarancón, O. (1989): «Propiedad y mercado inmobiliario en Madrid, 1885 (II. El mercado inmobiliario)», in A. Bahamonde and L. Otero (eds), La sociedad madrileña durante la Restauración, 1876-1931. Madrid: Comunidad de Madrid, pp. 151-160.

Ayuntamiento De Madrid (1929): Información sobre la Ciudad: Memoria. Madrid: Ayuntamiento de Madrid. 
Bassols Coma, M. (1973): Génesis y evolución del derecho urbanístico español (18121956). Madrid: Montecorvo.

Bono, J. (1979): Historia del derecho notarial español. Madrid: Junta de decanos de los colegios Notariales de España.

Berndt, E. R., and Griliches, Z. (1993): «Price Indexes for Microcomputers: An Exploratory Study», in M. F. Foss; M. E. Manser, and A. H. Young (eds), Price Measurements and Their Uses. Chicago: University of Chicago Press, pp. 63-93.

CARMOnA, J., and Rosés, J. R. (2012): «Land Markets and Agrarian Backwardness (Spain, 1900-1934)». European Review of Economic History 16 (1), pp. 74-96.

Case, B.; Pollakowski, H., and Wachter, S. (1991): "On Choosing Among House Price Index Methodologies». Journal of the American Real Estate and Urban Economic Association 19 (3), pp. 286-307.

Coase, R. H. (1960): «The Problem of Social Cost». Journal of Law and Economics 3, pp. 1-44.

Collins, W. J., and MARGO, R. A. (2003): "Race and the Value of Owner-Occupied Housing, 1940-1990». Regional Science and Urban Economics 33 (3), pp. 255-286.

Comisión De Reformas Sociales (1985): Información oral y escrita. Madrid: Ministerio de Trabajo y Seguridad Social, 1985 [1889-1893].

Demsetz, H. (1967): «Towards a Theory of Property Rights». American Economic Review 57 (2), pp. 347-373.

Diewert, W. E. (2006): «The Paris OECD-IMF Workshop on Real Estate Price Indexes: Conclusions and Future Directions», in W. E Diewert; B. M. Balk; D. Fixler; K. J. Fox, and A. O. Nakamura (eds), Price and Productivity Measurement. Housing, vol. 1. Victoria, BC: Trafford Press, pp. 87-116.

Fernández Clemente, E., and Forcadell, C. (1992): «Crecimiento económico, diversificación social y expansión urbana en Zaragoza, 1900-1930», in J. L. García Delgado (ed.), Las ciudades en la modernización de España. Los decenios interseculares. Madrid: Siglo XXI, pp. 433-460.

Galiana, L., and Llop, M. (1989): «Propiedad y mercado inmobiliario en Madrid, 1885 (I. Propiedad)», in A. Bahamonde and L. Otero (eds), La sociedad madrileña durante la Restauración, 1876-1931. Madrid: Comunidad de Madrid, pp. 161-174.

García Delgado, J. L. (ed.), (1992): Las ciudades en la modernización de España. Los decenios interseculares. Madrid: Siglo XXI.

Gouriéroux, C., and Laferrère, A. (2009): "Managing Hedonic Housing Price Indexes: The French Experience». Journal of Housing Economics 18 (3), pp. 206-213.

Hauser, F. (1902): Madrid bajo el punto de vista médico-social. Madrid: Sucesores de Rivadeneyra, 1902.

Hulten, C. R. (2008): «Divisia index», in S. N. Durlauf and L. E. Blume (eds), The New Palgrave Dictionary of Economics, 2nd edn. Basingstoke: Palgrave Macmillan, pp. 899-901.

Instituto De Reformas Sociales (1920): Preparación de las bases para un proyecto de Ley de casas para obreros. Madrid: Minuesa.

Instituto De Reformas Sociales (1921): Anteproyecto de reforma de la Ley de 12 de junio de 1911 relativa a construcción de casas baratas. Madrid: Minuesa.

JAFFE, A. J., and Louziotis, D. JR (1996): «Property Rights and Economic Efficiency: A Survey of Institutional Factors». Journal of Real Estate Literature 4, pp. 137-159.

JimenEZ, E. (1984): «Tenure security and urban squatting». Review of Economics and Statistics 66 (2), pp. 556-567.

Malpezzi, S. (1999): «Economic Analysis of Housing Markets in Developing and Transition Economies», in P. C. Cheshire and E. S. Mills (eds), Handbook of Regional and Urban Economics, vol. 3. Amsterdam: Elsevier, pp. 1791-1864. 
Martín Aceña, P. (1985): «Desarrollo y modernización del sistema financiero, 18441935», in N. Sánchez-Albornoz (ed.), La modernización económica de España 1830-1930. Madrid: Alianza Universidad, pp. 121-146.

Martínez Alcubilla, M. (1892-1894): Diccionario de la administración española: compilación de la novísima legislación de España peninsular y ultramarina en todos los ramos de la administración pública. Madrid: Ministerio de Gracia y Justicia.

NuÑEz Granés, P. (1920): El problema de la urbanización del extrarradio de dicha Villa desde los puntos de vista técnico, económico, administrativo y legal. Madrid: Ayuntamiento de Madrid.

Ortego, P. (2006): Las Casas Baratas. La obra del Instituto de Reformas Sociales. Madrid: IUSTEL, 2006.

Pérez MoredA, V. (1985): «La población española en el siglo xix y el primer tercio del XX (Limitaciones y cronología de la modernización demográfica en España)», in N. Sánchez-Albornoz (ed.), La modernización económica de España 1830-1930. Madrid: Alianza Universidad, pp. 121-146.

Peset, M. (1978): «Los orígenes del registro de la propiedad en España». Revista crítica de derecho inmobiliario 527, pp. 695-716.

Prados De La Escosura, L. (2003): El progreso de España, 1850-2000. Madrid: Fundación BBVA.

Prados De La Escosura, L., and Rosés, J. R. (2009): «The Sources of Long-Run Growth in Spain 1850-2000». Journal of Economic History 69 (4), pp. 1063-1091.

Prados De La Escosura, L., and Rosés, J. R. (2010): "Long-Run Estimates of Physical Capital in Spain, 1850-2000». Research in Economic History 27, pp. 141-200.

ReHER, D. S. (1986): «Desarrollo urbano y evolución de la población: España 17871930 ». Revista de Historia Económica 4 (1), pp. 39-66.

Rodríguez Chumillas, I. (1989): «La propiedad Inmobiliaria en Madrid: 1870-1890», in A. Bahamonde and L. Otero (eds), La sociedad madrileña durante la Restauración, 1876-1931. Madrid: Comunidad de Madrid, pp. 175-180.

Rosés, J. R.; Martinez-Galarraga, J., and Tirado, D. A. (2010): «The Upswing of Regional Income Inequality in Spain (1860-1930)». Explorations in Economic History 47 (2), pp. 244-257.

Rosés, J. R., and Sánchez-Alonso, B. (2004): «Regional Wage Convergence in Spain 1850-1930». Explorations in Economic History 41 (4), pp. 404-425.

SiLVESTRE, J. (2005): «Internal migrations in Spain, 1877 1930». European Review of Economic History 9 (2), pp. 233-265.

Sorribes Monrabal, J. (1992): «La transición urbana: método y resultados. Valencia 1874-1931», in J. L. García Delgado (ed.), Las ciudades en la modernización de España. Los decenios interseculares. Madrid: Siglo XXI, pp. 197-222.

TAFUnELl, X. (1992): «La construcción en Barcelona, 1860-1935: continuidad y cambio», in J. L. García Delgado (ed.), Las ciudades en la modernización de España. Los decenios interseculares. Madrid: Siglo XXI, pp. 3-20.

TAFunEll, X. (2005): "Urbanización y vivienda», in A. Carreras and X. Tafunell (eds), Estadísticas históricas de España: siglo XIX-XX, vol. 1. Madrid: Fundación BBVA, pp. 455-499.

Triplett, J. (2006): Handbook on Hedonic Indexes and Quality Adjustments in Price Indexes: Special Application to Information Technology Products. Paris: OECD.

Williamson, J. G. (1990): Coping with City Growth During the British Industrial Revolution. Cambridge: Cambridge University Press. 
Williamson, J. G. (1994): «Coping with City Growth», in R. Floud and D. N. McCloskey (eds), The Economic History of Britain Since 1700-1870, vol. 1, 2nd edn. Cambridge: Cambridge University Press, pp. 332-356.

Williamson, O. E. (1975): Markets and Hierarchies: Analysis and Antitrust Implications. New York: Free Press.

\section{APPENDIX INDICES OF SPANISH HOUSING PRICES}

TABLE A1

SPANISH HOUSING PRICES, 1904-34 (1904 = 100)

\begin{tabular}{|l|c|r|r|r|r|c|}
\hline & \multicolumn{3}{|c|}{ Market transactions } & \multicolumn{2}{c|}{ Non-market transactions } \\
\hline & Nominal & Real & Hedonic & Nominal & Real & Hedonic \\
\hline & $\mathbf{( 1 )}$ & $\mathbf{( 2 )}$ & $\mathbf{( 3 )}$ & $\mathbf{( 4 )}$ & $\mathbf{( 5 )}$ & $\mathbf{( 6 )}$ \\
\hline 1904 & 100.00 & 100.00 & 100.00 & 100.00 & 100.00 & 100.00 \\
1905 & 91.40 & 94.94 & 94.43 & 106.93 & 108.25 & 110.00 \\
1906 & 96.97 & 103.23 & 101.10 & 105.78 & 107.99 & 112.71 \\
1907 & 89.24 & 95.57 & 94.76 & 108.18 & 108.93 & 113.40 \\
1908 & 93.50 & 99.76 & 98.50 & 105.98 & 109.52 & 116.49 \\
1909 & 92.03 & 101.07 & 101.14 & 91.65 & 106.01 & 115.27 \\
1910 & 91.01 & 100.48 & 100.93 & 87.24 & 101.06 & 112.35 \\
1911 & 90.44 & 95.09 & 95.07 & 89.40 & 92.49 & 104.56 \\
1912 & 99.54 & 101.79 & 101.49 & 96.38 & 99.75 & 113.58 \\
1913 & 98.52 & 101.70 & 100.85 & 100.38 & 99.65 & 114.50 \\
1914 & 95.84 & 95.74 & 94.67 & 98.13 & 94.80 & 109.43 \\
1915 & 90.99 & 81.11 & 81.85 & 98.60 & 90.45 & 107.05 \\
1916 & 94.81 & 80.69 & 80.76 & 110.28 & 90.79 & 105.61 \\
1917 & 114.48 & 85.36 & 84.89 & 98.45 & 73.15 & 88.66 \\
1918 & 145.30 & 95.68 & 92.38 & 105.76 & 72.70 & 89.43 \\
1919 & 159.66 & 99.45 & 96.39 & 107.49 & 67.58 & 85.19 \\
1920 & 183.67 & 108.70 & 104.78 & 102.24 & 59.31 & 74.47 \\
1921 & 141.22 & 84.98 & 81.86 & 119.48 & 69.80 & 88.35 \\
1922 & 142.22 & 85.24 & 82.68 & 119.15 & 71.57 & 88.53 \\
1923 & 146.11 & 88.67 & 84.89 & 127.88 & 75.93 & 93.22 \\
1924 & 143.88 & 86.83 & 85.37 & 137.39 & 83.04 & 102.53 \\
1925 & 169.16 & 100.30 & 97.08 & 129.71 & 79.04 & 99.99 \\
1926 & 165.55 & 99.07 & 98.31 & 155.31 & 94.48 & 118.94 \\
1927 & 151.69 & 96.02 & 93.37 & 134.76 & 83.21 & 109.11 \\
\hline
\end{tabular}


TABLE A1 (Cont.)

\begin{tabular}{|l|c|c|c|c|c|c|}
\hline & \multicolumn{3}{|c|}{ Market transactions } & \multicolumn{3}{c|}{ Non-market transactions } \\
\hline & Nominal & Real & Hedonic & Nominal & Real & Hedonic \\
\hline & $\mathbf{( 1 )}$ & $\mathbf{( 2 )}$ & $\mathbf{( 3 )}$ & $\mathbf{( 4 )}$ & $\mathbf{( 5 )}$ & $\mathbf{( 6 )}$ \\
\hline 1928 & 140.41 & 86.51 & 82.14 & 122.57 & 72.34 & 91.33 \\
1929 & 158.78 & 93.97 & 82.69 & 137.08 & 84.68 & 103.00 \\
1930 & 197.29 & 119.84 & 110.21 & 166.30 & 96.43 & 115.47 \\
1931 & 199.37 & 119.16 & 107.30 & 210.53 & 118.74 & 128.68 \\
1932 & 160.78 & 103.07 & 95.48 & 213.56 & 122.35 & 130.38 \\
1933 & 161.63 & 107.15 & 98.30 & 236.45 & 137.95 & 141.49 \\
1934 & 227.35 & 141.93 & 121.65 & 247.96 & 139.74 & 133.86 \\
\hline
\end{tabular}

Notes and sources: See Figure 1 and text.

FIGURE A1

COMPARISON OF REAL AND HEDONIC PRICE INDICES FOR MARKET TRANSACTIONS (PRICE PAID) AND NON-MARKET TRANSACTIONS (NO PRICE PAID), 1904-1934 $(1900=100)$

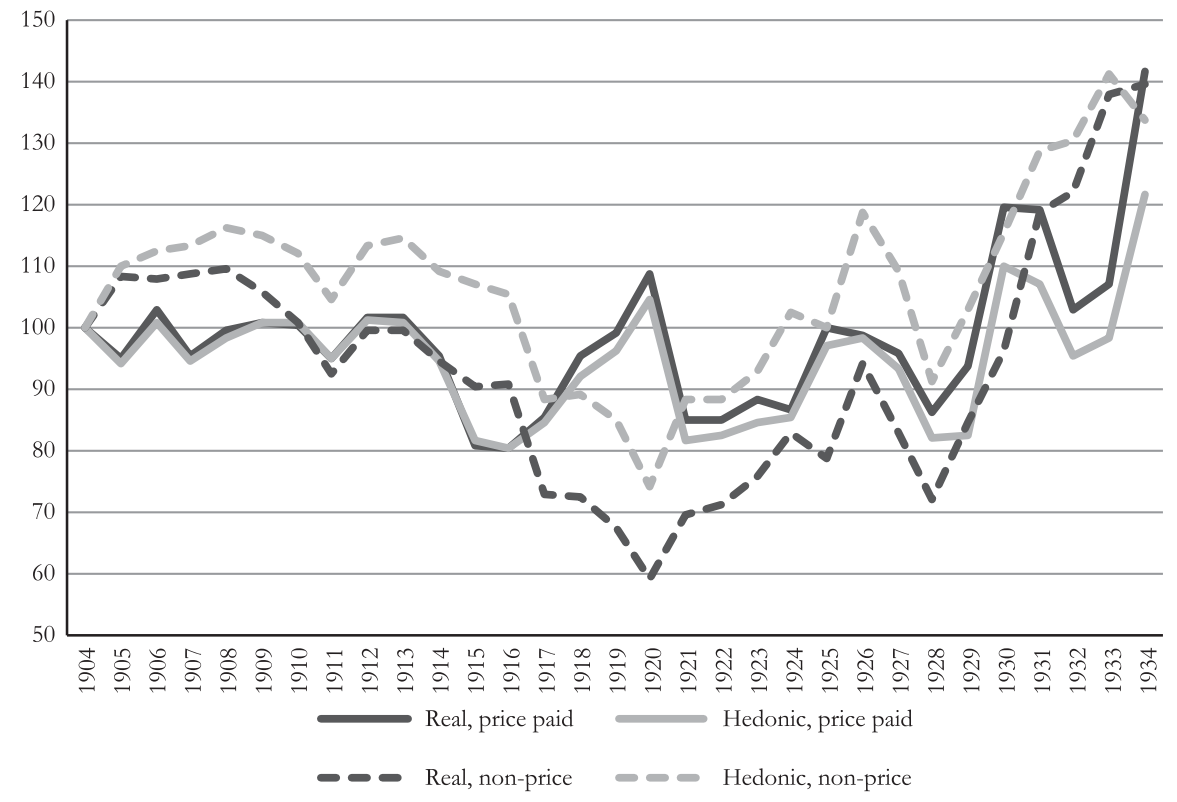

